4. Кримінальний Кодекс України: станом на 05.01.2017 р. / Верховна Рада України // Офіційний вісник України 2001, 21 від 08.06.2001. Ст. 920.

5. Заява Верховної Ради України до Міжнародного кримінального суду «про визнання Україною юрисдикції міжнародного кримінального суду щодо скоєння злочинів проти людяності вищими посадовими особами держави, які призвели до особливо тяжких наслідків та масового вбивства українських громадян під час мирних акцій протестів у період з 21 листопада 2013 року по 22 лютого 2014 року» [Електронний ресурс]: [Веб сайт] https://zakon.rada.gov.ua/laws/show/790-18\#Text (дата звернення: 12.03.2021)

6. Заява Верховної Ради України до Міжнародного кримінального суду «Про визнання Україною юрисдикції Міжнародного кримінального суду щодо скоєння злочинів проти людяності та воєнних злочинів вищими посадовими особами Російської Федерації та керівниками терористичних організацій «ДНР» та «ЛНР», які призвели до особливо тяжких наслідків та масового вбивства українських громадян» [Електронний ресурс] : [Веб сайт] https://zakon.rada.gov.ua/laws/show/14519\#Text (дата звернення: 12.03.2021)

DOI https://doi.org/10.30525/978-9934-26-074-2-57

\title{
СЛУЖБОВІ ЗЛОВЖИВАННЯ У СТРУКТУРІ КОРУПЦІЙНИХ КРИМІНАЛЬНИХ ПРАВОПОРУШЕНЬ
}

\author{
Харченко В. Б. \\ доктор юридичних наук, професор, \\ завідувач кафедри кримінального права та кримінологіі \\ факультету № 6 \\ Харківського начіонального університету внутрішніх справ \\ м. Харків, Україна
}

Зміна пріоритетів у відносинах держави та особи, переорієнтація ставлення до особи як до вищої соціальної цінності й потреба у перетворенні України на «державу для людини» викликали необхідність розглядати органи державної влади та органи місцевого самоврядування, їх посадових осіб, з одного боку, як таких, що перебувають на службі у суспільства, а з іншого - як гарантів забезпечення охорони прав і свобод людини та громадянина, власності, громадського порядку й громадської безпеки, довкілля, конституційного устрою України від зло- 
чинних посягань [8, с. 176]. У цьому контексті актуалізується питання теоретичного обгрунтування та правового врегулювання сутності зловживання владою або службовим становищем у структурі корупційних кримінальних правопорушень.

Визначаючи зміст ознаки «шляхом зловживання службовим становищем», у першу чергу необхідно звернутися до положень ч. 2 ст. 19 Конституції України, яка визначає, що службові особи органів державної влади та органів місцевого самоврядування зобов'язані діяти лише на підставі, в межах повноважень та у спосіб, що передбачені Конституцією та законами України, тобто наведена норма визначає порогові обмеження діяльності службових осіб: підстави, межі та спосіб, які встановлюються відповідним нормативним актом, що регламентує повноваження конкретної посадової особи або щодо загального кола іiі повноважень, або визначає конкретні права та обов'язки щодо ввірених їм чи наданих у безпосереднє відання предметів чи предметів, щодо яких службова особа має право оперативного управління. Такі повноваження службової особи можуть бути визначені Законами України «Про державну службу», «Про службу в органах місцевого самоврядування», «Про статус депутатів місцевих рад», «Про Національну поліцію» тощо.

У спеціальній літературі службові зловживання розглядаються як правило залежно від сутності суспільно небезпечного діяння, а саме: 1) зловживання владою; 2) зловживання становищем; 3) зловживання повноваженнями [1, с. 77-78]. В. Г. Хашев класифікує службові зловживання залежно від способу їх вчинення: 1) вчинене способом використання службовою особою наданої влади; 2) вчинене способом використання службовою особою свого службового становища [7, с. 41]. Саме таку позицію слід вважати більш обгрунтованою, адже термін «повноваження» має тлумачення як право, надане кому-небудь для здійснення чогось; права, надані особі або підприємству органами влади [9, с. 387], тобто під зловживанням повноваженнями буквально слід розуміти зловживання правом.

Водночас, термін «становище» визначається як ті чи інші обставини, умови, в яких хто-, що-небудь перебуває; умови існування кого-небудь; сукупність обставин, які створюють ту чи іншу ситуацію; посада; посідати провідне становище [9, с. 401]. Саме у такому значенні закон про кримінальну відповідальність і розглядає службові зловживання, що полягають у вчиненні службовою особою кримінально-протиправної поведінки в обстановці виконання такою особою покладених на неї обов'язків та реалізацію наданих їй прав, але 3 порушенням (недотриманням, перевищенням) конкретних юридичних приписів. Про зловживання саме службовим становищем як ознаки корупційних злочинів 
наголошується і у примітці до ст. 45 КК України. На такий саме спосіб вчинення конкретних корупційних злочинів зазначається і у диспозиціях ч. 2 ст. 191 , ч. 2 ст. 262 , ч. 2 ст. 308 , ч. 2 ст. 312 , ч. 2 ст. 313 , ст. 357 та ч. 2 ст. 410 КК України.

Водночас, вказівка у назві та диспозиції ст. 364 КК України на можливість зловживання не тільки службовим становищем, а і владою, обумовлює необхідність з'ясування сутності та співвідношення наведених понять. У доктрині кримінального права під зловживанням владою розуміють умисне використання представником влади або особою, яка виконує організаційно-розпорядчі обов'язки, всупереч інтересам служби наданих їй прав 3 пред'явлення вимог та прийняття рішень, обов'язкових для виконання іншими фізичними та юридичними особами [4, с. 71]. Порівнюючи обсяг наведених понять, М. І. Мельник обгрунтовано визнає зловживання службовим становищем більш широким поняттям, що охоплює за своїм змістом зловживання владою, оскільки використовувати всупереч інтересам служби службова особа може i владні права та можливості, якщо вона ними наділена [5, с. 280]. Таким чином йдеться про співвідношення наведених понять як частини та цілого як у назві, так й у диспозиції низки статей КК України.

Отже, службове зловживання - це будь-яке умисне використання службовою особою всупереч інтересам служби своїх прав і можливостей, що були їй надані для виконання своїх службових обов’язків. Таке використання припускає реалізацію тих прав і повноважень, якими службова особа наділена, займаючи відповідну посаду або здійснюючи певну службову діяльність і завжди пов'язане 3 соціально-правовим статусом службової особи (сукупністю його прав та обов'язків, що утворюють службову компетенцію винного) та його соціальним значенням (службовий авторитет особи або органу, який особа представляє i у якому вона здійснює свою службову діяльність, наявність пов'язаних iз службовими повноваженнями можливостей, що обумовлені займаною посадою) [6, с. 15].

Саме тому, характеризуючи спосіб вчинення корупційних кримінальних правопорушень законодавець вказує на можливості їх вчинення саме шляхом зловживання службовою особою своїм службовим становищем. На цьому наголошується i в основних міжнародно-правових актах щодо протидії корупції. Так, ст. 19 «Зловживання службовим становищем» Конвенції ООН проти корупції, визначає, що кожна Держава-учасниця розглядає можливість вжиття таких законодавчих та інших заходів, які можуть бути необхідними для визнання злочином умисного зловживання службовими повноваженнями або службовим становищем, тобто здійснення будь-якої дії чи утримання від здійснення 
дій, що є порушенням законодавства державною посадовою особою під час виконання своїх функцій з метою одержання будь-якої неправомірної вигоди для самої себе чи іншої фізичної або юридичної особи [2].

На обгрунтованість визнання зловживання службовою особою своїм службовим становищем найбільш широким способом вчинення як корупційних кримінальних правопорушень, передбачених ч. 2 ст. 191, ч. 2 ст. 262 , ч. 2 ст. 308 , ч. 2 ст. 312 , ч. 2 ст. 313 , ст. 357 та ч. 2 ст. 410 КК України, так і суспільно небезпечних посягань, передбачених статтями 364 та 364-1 КК України, вказує і та обставина, що у разі буквального (адекватного) тлумачення способів вчинення наведеної кримінально протиправної поведінки, дійсний зміст норми закону про кримінальну відповідальність точно (буквально) відповідає іiі текстовому виразу (тексту та букві закону) [3, с. 198]. Відсутні підстави кримінальної відповідальності за корупційне кримінальне правопорушення у разі незаконного заволодіння предметами, передбаченими ч. 2 ст. 262, ч. 2 ст. 308 , ч. 2 ст. 312 , ч. 2 ст. 313 , ст. 357 та ч. 2 ст. 410 КК України, у разі, якщо таке заволодіння вчиняється шляхом їх привласнення або розтрати, адже примітка до ст. 45 КК зазначає саме на можливість вчинення кримінальних правопорушень цієї групи виключно шляхом зловживання службовою особою своїм службовим становищем.

\section{Література:}

1. Киричко В. М. Кримінальна відповідальність за корупцію. Харків : Право, 2013. 424 с.

2. Конвенція ООН проти корупції: $\mathrm{OOH}$ : Міжнародний документ від 31.10.2003. URL: http://zakon2.rada.gov.ua/laws/show/995_c16.

3. Коханюк Т. С. Системне тлумачення кримінального закону : монографія. Львів : ЛьвДУВС, 2015. 263 с.

4. Кримінальна відповідальність за окремі злочини у сфері службової діяльності та професійної діяльності, пов'язаної з наданням публічних послуг: наук.-практ. посіб. / за заг. ред. Ю. В. Ударцова; Ген. прокуратура України, Нац. акад. прокуратури України. Київ : Правова єдність : Алерта, 2013. 179 с.

5. Мельник, Микола Іванович. Кримінологічні та кримінальноправові проблеми протидії корупції : дис... д-ра юрид. наук: 12.00.08 / Нац. акад. внутр. справ України. Київ, 2002. 506 арк.

6. Мельникова В. Е. Должностные преступления. Вопросы уголовноправовой квалификации: учебное пособие / отв. ред. Б. В. Здравомыслов. Москва, 1985. 97 с.

7. Хашев, Вадим Георгійович. Кримінальна відповідальність за зловживання владою або службовим становищем : дис... канд. юрид. 
наук : 12.00 .08 / Дніпропетр. держ. ун-т внутр. справ. Дніпропетровськ, 2007. 258 арк.

8. Шиндель Ю. І. Зміст надання публічних послуг у складі злочину, передбаченому ст. 365-2 КК України // Вісн. Харк. нац. ун-ту ім. В. Н. Каразіна. Сер. : Право. 2013. № 1082. С. 173-177.

9. Яковлева А. М. Сучасний тлумачний словник української мови : 55000 слів. Харків : Торсінг, 2017. 672 с.

DOI https://doi.org/10.30525/978-9934-26-074-2-58

\title{
DEVELOPMENT OF SURVEILLANCE TECHNOLOGIES AS A FACTOR OF COMBATING CRIME BY COLLECTING INFORMATION OF PRIVATE CHARACTER
}

\author{
Khlopov A. A. \\ Postgraduate Student \\ Kharkiv National University of Internal Affairs \\ Kharkiv, Ukraine
}

In the modern world, technology has become an integral part of the life of mankind. This made it possible to redistribute some of the complex tasks for a person to perform on equipment, thereby saving time and effort. From purely pragmatic motives, the automation of production has created the prerequisites for rapid socio-economic development in the world and an increase in the well-being of the population in many regions. In parallel with this, a significant part of the technology is used to perform socially useful tasks, such as ensuring public safety and law and order. First of all, this applies to various camera-fixing devices, which have become widespread and are actively used to improve the law enforcement system and prevent the commission of crimes. However, as a result of their work, various kinds of information of private character are fixed, which leads to the disclosure of the sphere of his private life by the aspect. This creates additional risks of an attack on the rights and freedoms of citizens, as well as abuse by the competent authorities of the state. Therefore, the problem of using surveillance devices and analyzing their impact on privacy looks especially relevant today.

In general, the technological evolution of tracking devices has occurred in a relatively short period of time. The development of the project for the first video surveillance system is attributed to the German engineer Walter Bruch, which was later installed by Siemens in 1942. to monitor the testing of V-2 missiles $(1$, p. 60). In the future, such systems were actively used in testing 